\title{
Designing Augmented Reality-Based Computer Devices Learning Media on Android Platform
}

\author{
Dony Novaliendry ${ }^{1,2, *}$ Arif Subagia ${ }^{1}$ Titi Sriwahyuni ${ }^{1}$ Fegie Y Wattimena ${ }^{3}$ Axelon \\ S Renyaan ${ }^{3}$ Ceng-Hong Yang ${ }^{2}$ Putra Jaya $^{1}$
}

\author{
${ }^{I}$ Departement of Electronics Engineering, Faculty of Engineering, Universitas Negeri Padang, Padang, Indonesia \\ ${ }^{2}$ Departement of Electronics Engineering, National Kaohsiung University of Science and Technology, Kaohsiung, \\ Taiwan \\ ${ }^{3}$ Fakultas Sains \& Teknologi, Universitas Ottow Geissler Papua \\ *Corresponding author. Email:dony.novaliendry@ft.unp.ac.id
}

\begin{abstract}
IT technology is developing very rapidly. This is proven by the many discoveries about IT-based learning media, one of which is Augmented Reality. The media for introducing Augmented Reality-based computer devices can be used to overcome the lack of computer equipment used by schools during practice at SMK Srilangkat Tanjung Pura, resulting in ineffective teaching and learning activities and will take a long time. This happens because students have to take turns in using these learning tools. With the development of Augmented Reality in this learning media, the problem of lack of equipment can be resolved immediately. Augmented reality technology is used to display three-dimensional (3D) images on books that are connected using an Android phone. This media design uses Unity and Vuforia as the database. With this AR, it is hoped that students can learn quickly about the types of computer hardware whenever they want to use this media.
\end{abstract}

Keywords: Aumented Reality, learning tools, Android, Media

\section{INTRODUCTION}

The development of information technology makes various activities in human life change. Multiple actions have changed from manual practice to current, which is generally digital (using computers). People tend to use the latest method because it offers effectiveness and efficiency. The energy and efficiency can be seen in working time, automation, and ease of doing particular works. The demands of the present day are why people always develop information technology, making their work and other daily activities more efficient and effective. Communication technology is currently overgrowing. Along with the times, many people today use technology not only as a means of communication but as a tool to find various information and news on the internet [1][6][7][9].

The piece of technology that is now surged in popularity is Android. Android is an open-source operating system and provides convenience for users. The use of Android altered daily activities. When someone wants to read books, now that his/she doesn't need to carry books everywhere, they bring their Android phone/tablet [2][6][15]. The use of Android-based smartphones is growing in the business sector as well. Sales companies now offer their products to stores using Android-based tablets to display physical form, information, and how to use and perform the products sold. This process simplifies business processes and changes the conventional way.

Augmented Reality (AR) incorporates virtual objects into the real world in real-time by integrating objects in the 3-dimensional form [3][8]. System analysis is the decomposition of a complete system into parts to identify and evaluate existing errors. The system analysis consists of two components: the ongoing study and the proposed research [4].

AR was first developed in Sutherland in 1965. Researchers utilize this technology as a new way to increase productivity, effectiveness, efficiency, and entertainment media. AR has been widely used in entertainment, military training, medical, engineering design, robotics and telerobotics, manufacturing, education, etc. Several methods can be used in augmented reality, one of which is Marker-based tracking. The marker is usually a black and white illustration of a rectangle with a bold black border and a white background. On a computer, you can recognize the 
position and orientation of the marker object and create a $3 \mathrm{D}$ virtual world, namely a point $(0,0,0)$ and an axis consisting of $\mathrm{X}, \mathrm{Y}$, and $\mathrm{Z}$. This marker-based tracking has been developed since the 1980s and began to be developed in the use of Augmented Reality.

The method used in Augmented Reality is the "Markerless Augmented Reality" by using this method. The user does not need a marker to display 3-dimensional images [3]. Ronald T. Azuma defines Augmented Reality as a combination of real and virtual objects in the natural environment, running interactively in real-time [5]. There is an integration between objects in three dimensions, namely virtual items integrated with the real world. Apart from adding virtual objects in the natural environment, augmented reality also can eliminate existing objects. Adding a virtual image layer can remove or hide the real environment from the user's view [10][11][12][13][14].

Artoolkit is a software library to build Augmented Reality (AR) in C / C ++ programming language. Android is an operating system for mobile devices that includes middleware and applications. Android also provides a common platform for developers to create their applications. Unity is a tool created to develop games that are designed to be easy to use. A blender is software for creating 3-dimensional images for free and popular among designers. Blender, compared to other applications of its kind, Blender has an advantage that makes this application popular.

This study aims at producing applications. The design of media recognition for computer devices is based on augmented reality on the android platform. With this application, it is expected that the teaching and learning process, which has found several deficiencies, can be resolved.

\section{METHOD}

\subsection{System Analysis}

\subsubsection{Running System Analysis}

Based on the analysis of the system that is running can be described as follows:

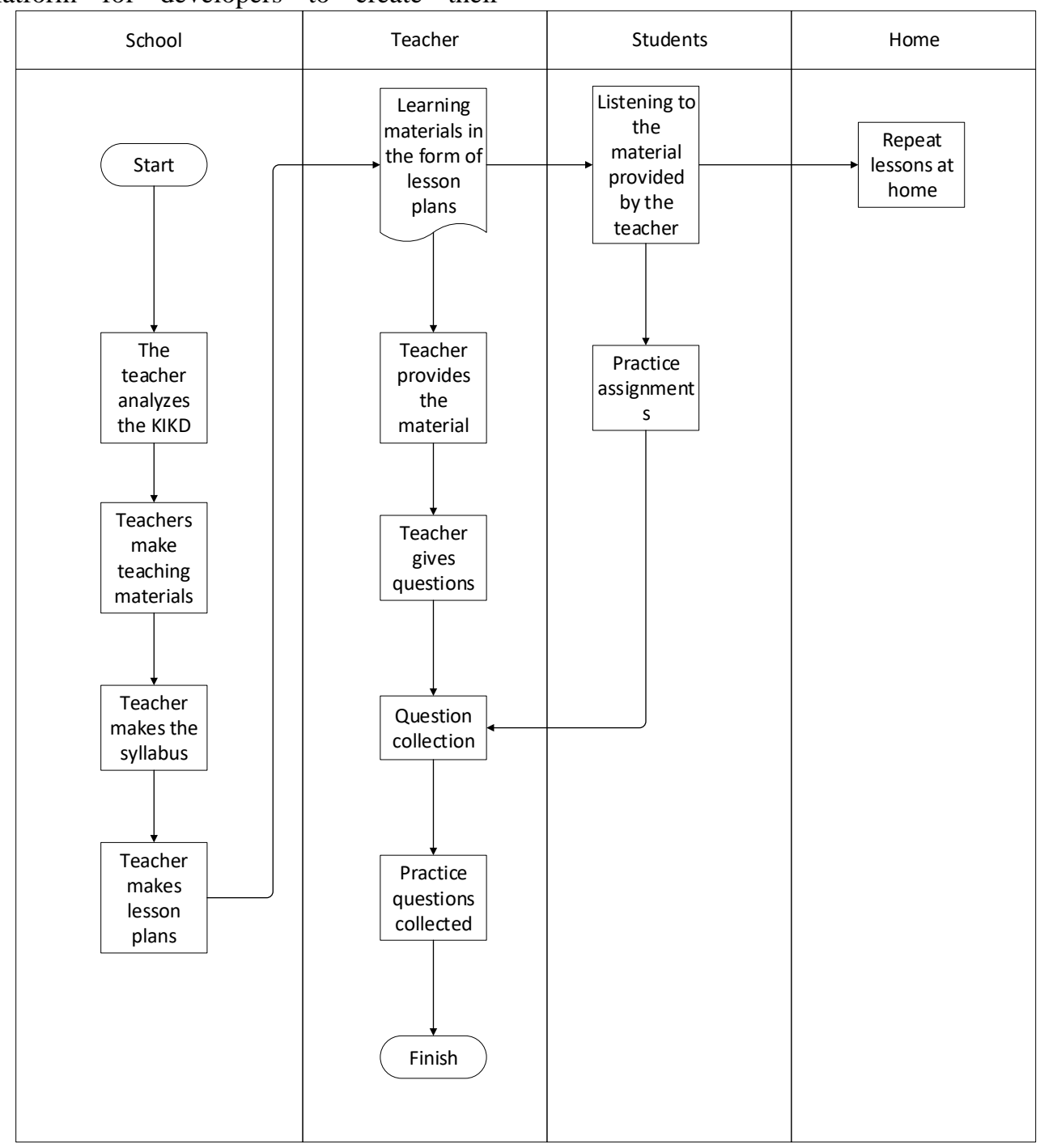

Figure 1. Running System Analysis 


\subsection{Proposed System Analysis}

The analysis problem then proposed a mobile application using the Android platform with Augmented Reality technology. Technology with mobile applications is easily accessible anywhere and is significantly developed globally, making it easier for the public to access this application. The advantages of augmented reality technology are also very prominent in terms of displaying information in real-time to be applied to applications to provide solutions to existing problems. The purpose of designing this application is to show data from a computer device in real-time without using a whole computer.

\subsection{System Design System}

The design is done to describe, plan, and make sketches or arrangements of several elements in a complete system.

\subsubsection{Use Case Diagram}

Use Case Diagram application media introduction to computer devices below:

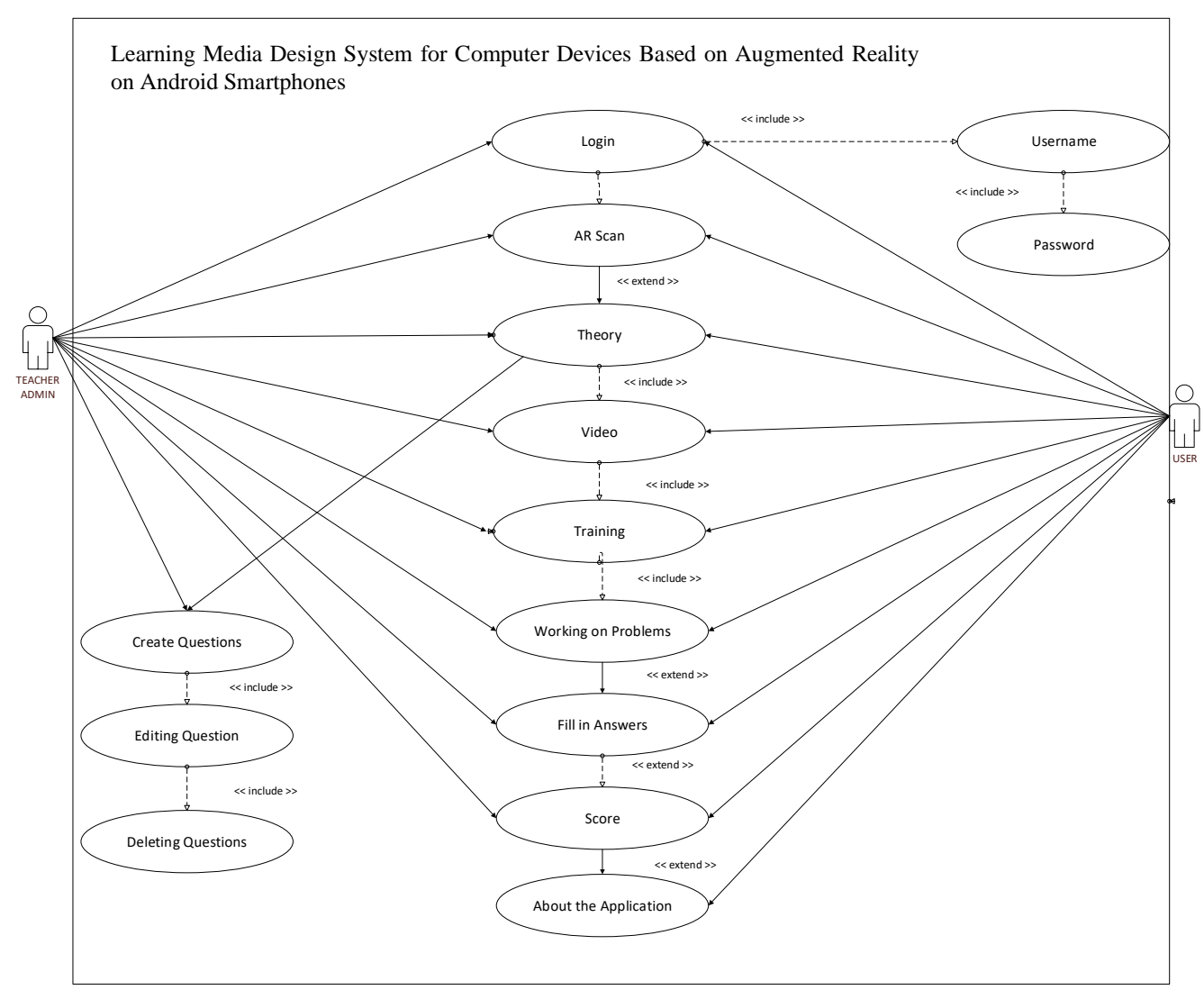

Figure 2. Use Case Diagram for Designing System Learning Media for Computer Devices Based on Augmented Reality on a Smartphone Android 


\subsubsection{Activity Diagram}

follows:

The aspect that needs to be considered is that the system's activity diagram can be carried out. As

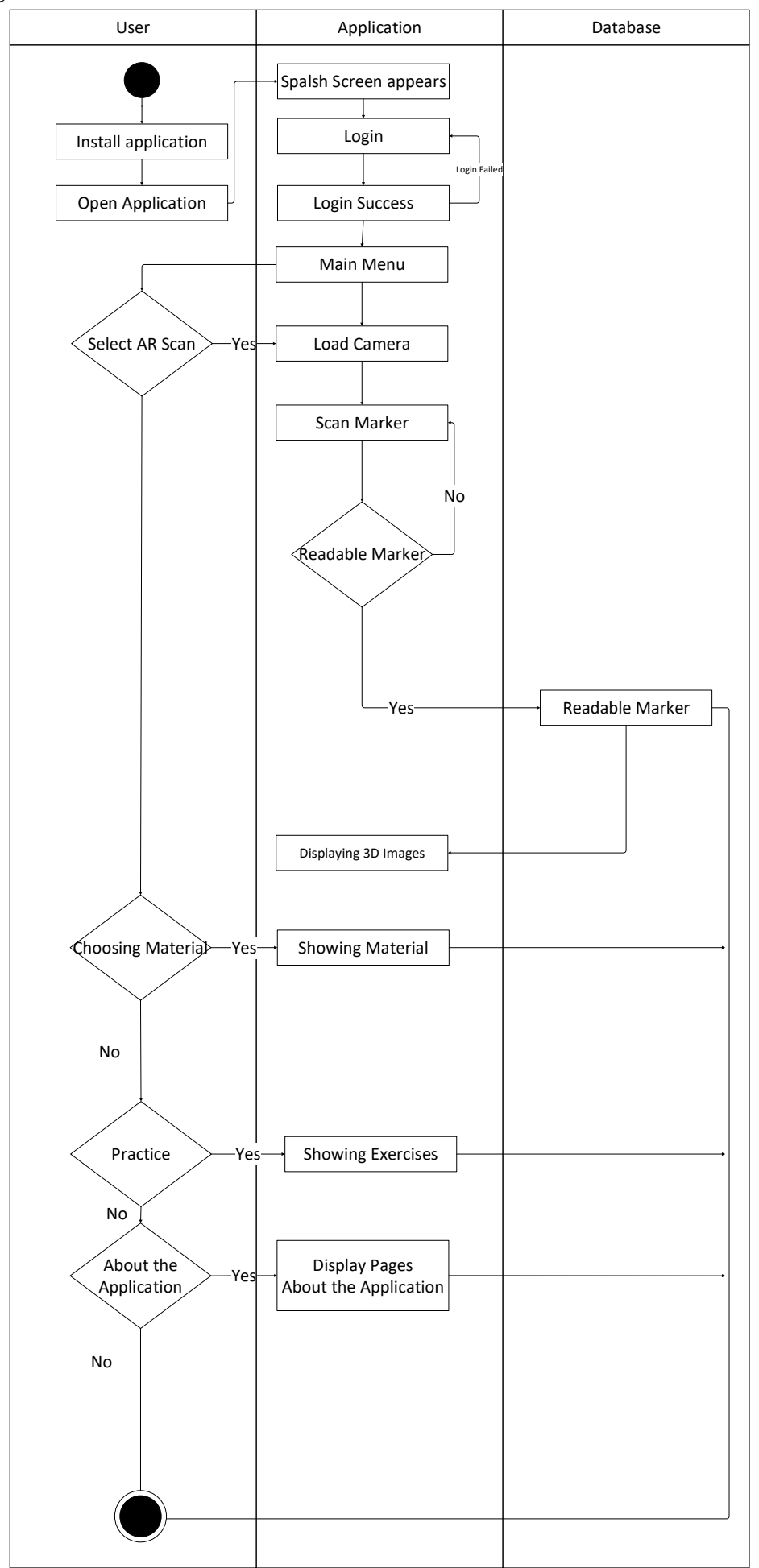

Figure 3. Activity Diagram. Flow Of activities in the system designed. 


\subsubsection{Login Activity Diagram}

It is the login activity of each student to enter the application. Each student must fill in the username form that has been provided so that the system can display the information needed in the application.

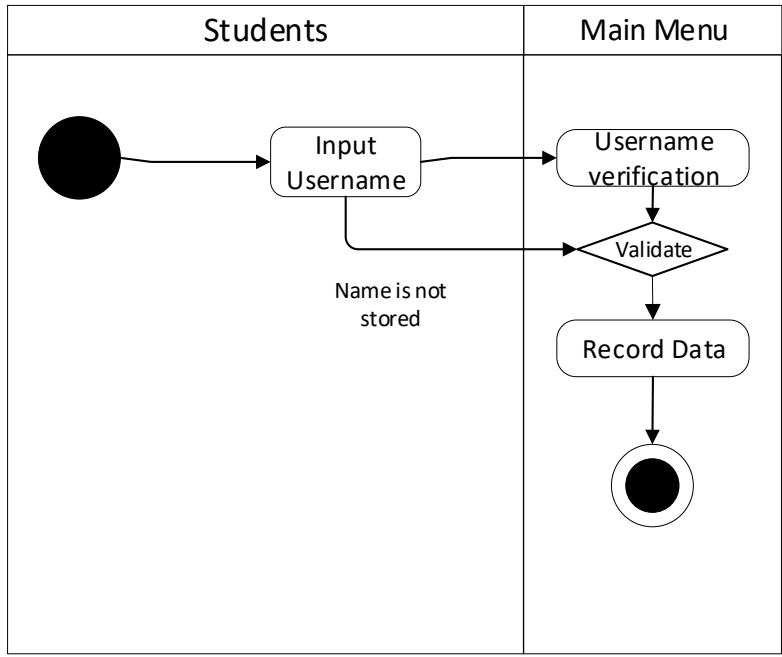

Figure 4. Login Activity Diagram

\subsubsection{Main Menu Activity Diagram}

It is the forefront for the application users if they want to use the application.

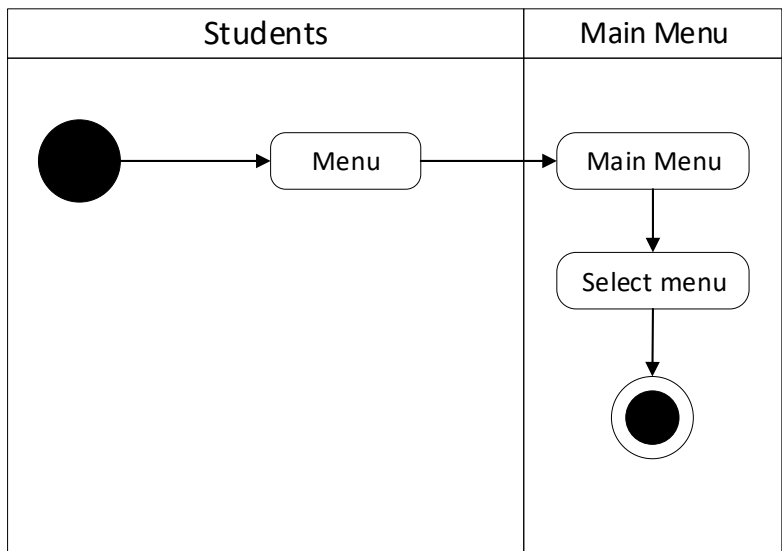

Figure 5. Main Menu Activity Diagram

\subsubsection{AR Scan Menu Activity Diagram}

It is the stage in opening a 3D image by discussing computer devices. Internet connection is not required to access this.

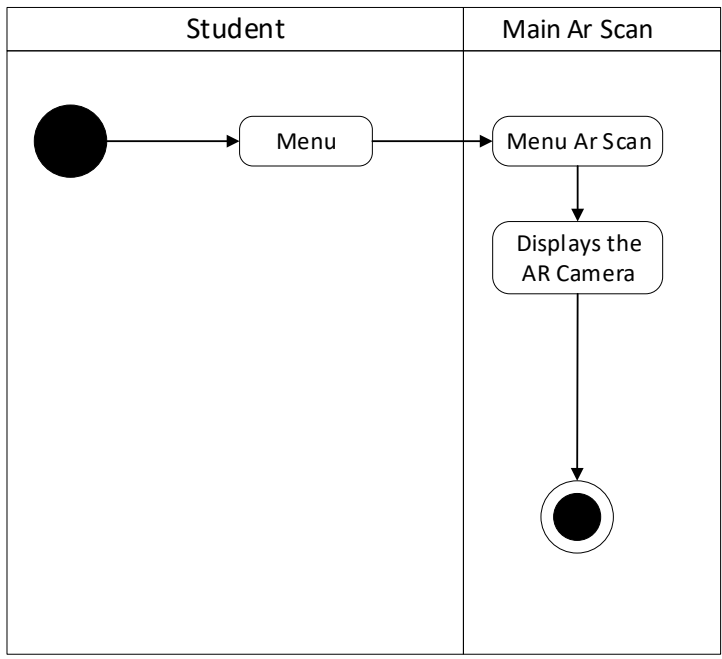

Figure 6. AR Scan Menu Activity Diagram

\subsubsection{Material Menu Activity Diagram}

It is a stage in opening material following the discussion of computer devices in the form of video. Accessing this does not require an internet connection.

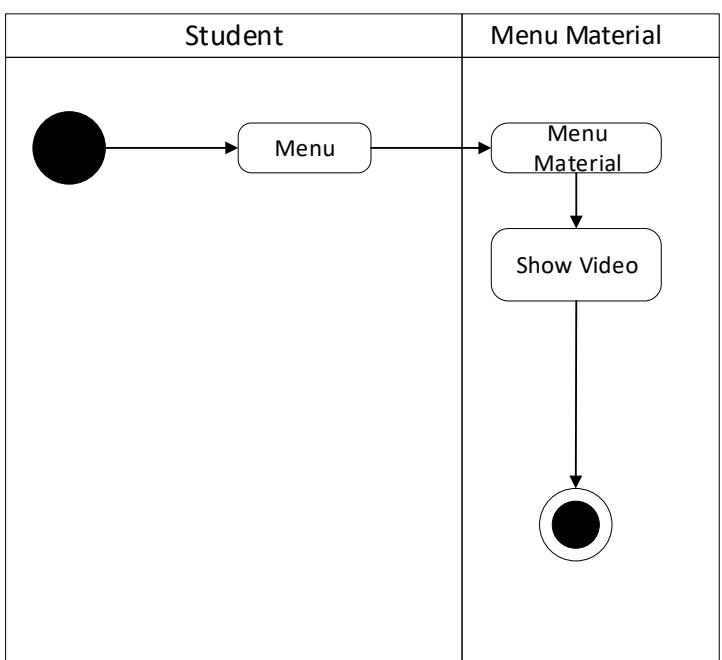

Figure 7. Material Menu Display Activity Diagram

\subsubsection{Exercise Menu Activity Diagram}

It is a stage in the opening of a quiz. At this stage, students choose the quiz menu, where each student completes the examination. The score of the results of working on the questions will be displayed. Pictures can be seen as follows: 


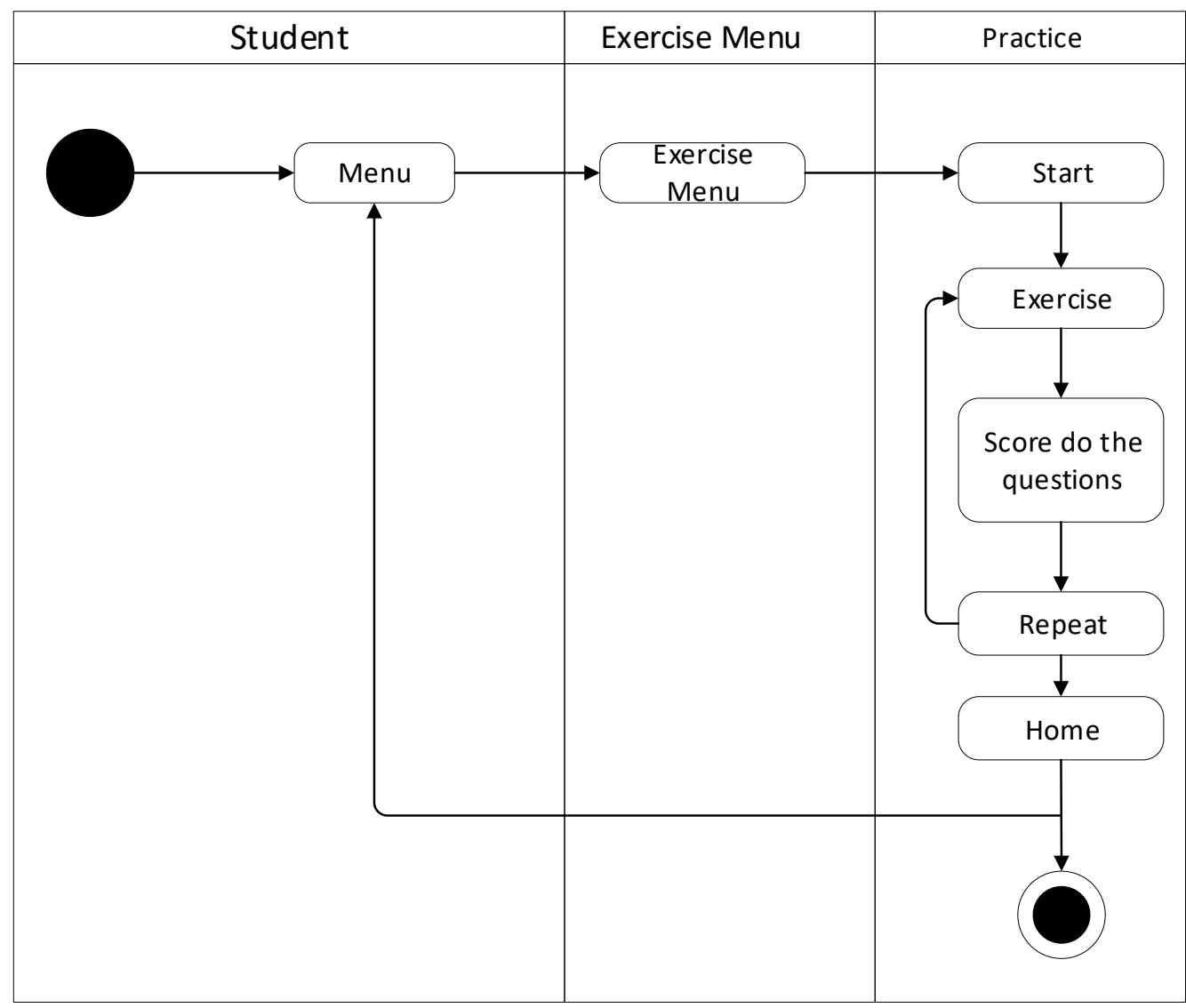

Figure 8. Exercise Menu Display Activity Diagram

\subsubsection{About the Application Activity Diagram}

It is a stage in opening About the Application, where this menu describes who the maker of the application is. Images can be seen on the following page.

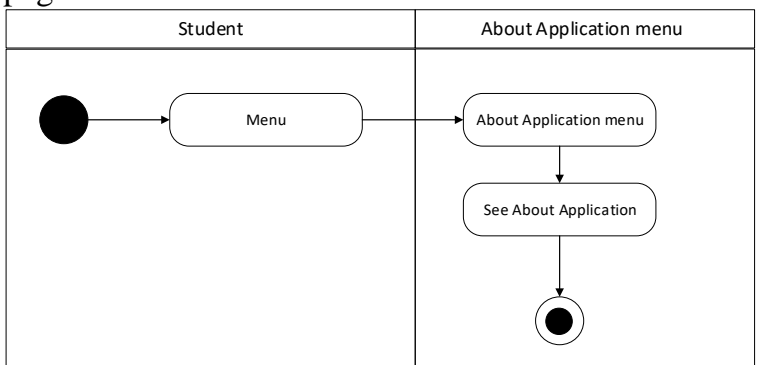

Figure 9. About the Application Menu Display Activity Diagram

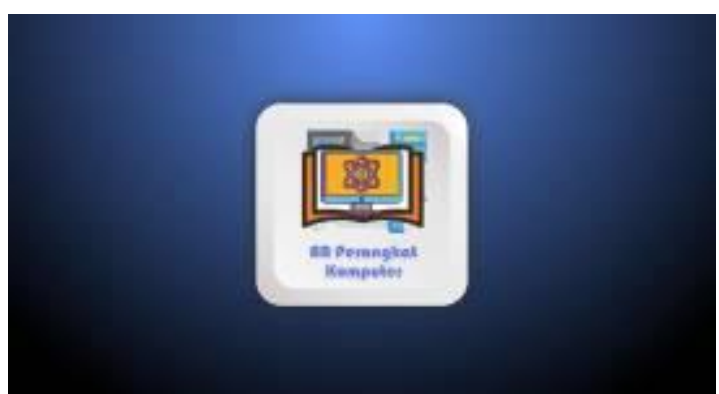

Figure 10. Splash Screen

\subsection{Loading Screen}

This display appears after the splash screen display-production of the loading process.

\section{RESULTS}

The results of the interface design of the media introduction to augmented reality-based computer hardware are as follows. Splash Screen display. This view displays the application logo created by the programmer. 


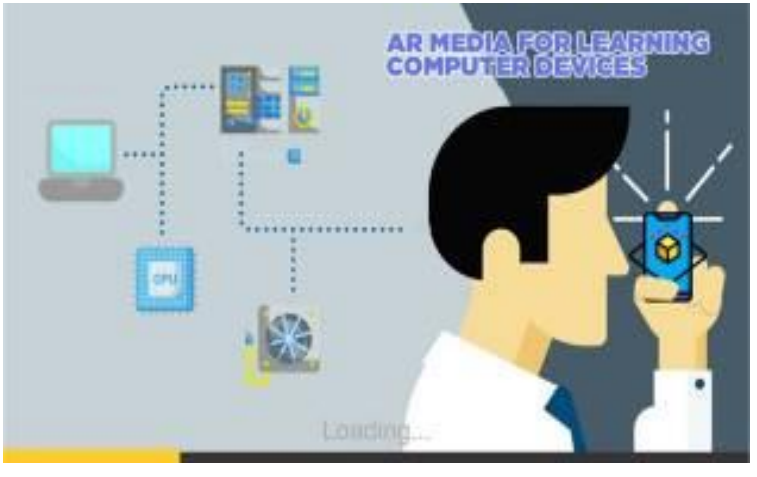

Figure 11. Loading Screen

\subsection{Main Menu Display}

Creating a user interface is made to simplify the use of applications. The main menu display displays the buttons of the application section.

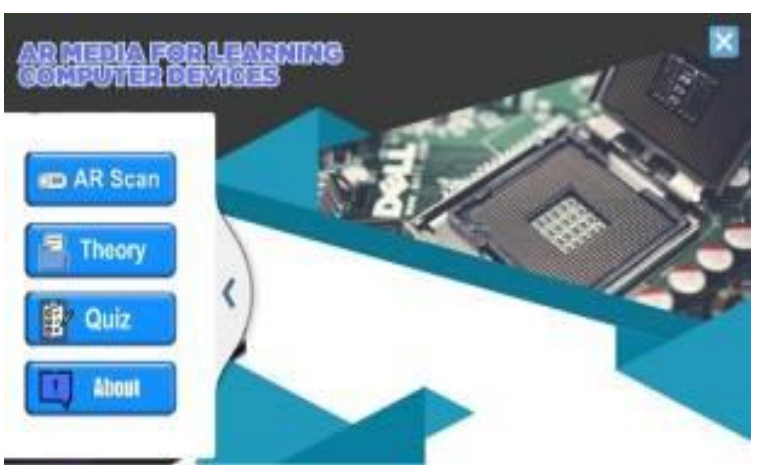

Figure 12. Main Menu For AR Media

\subsubsection{Display AR Scan (Camera) Display AR Scan}

Menu displays the camera perspective used on a smartphone and then displays 3D objects based on the detected markers. Here is a perspective view of the camera before seeing a feature.

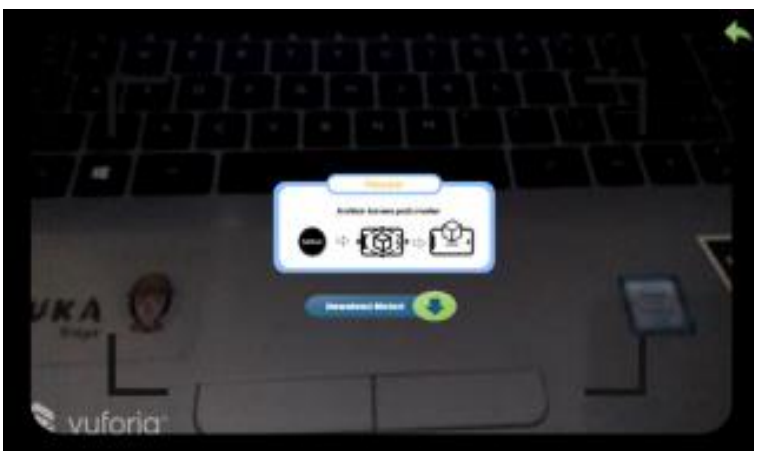

Figure 13. AR Camera view

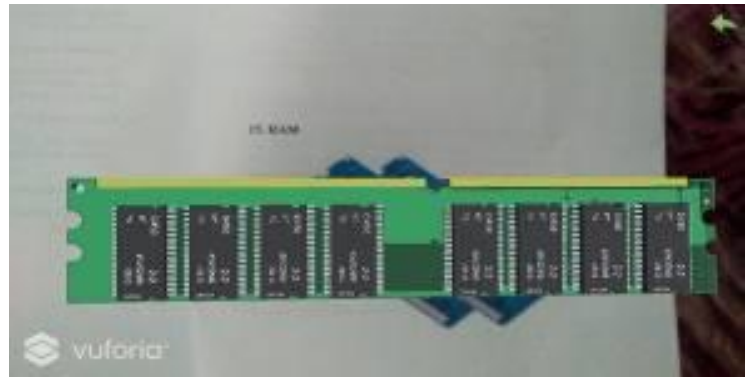

Figure 14. Scan AR

\subsection{Material Menu Display}

The material menu display shows the material contained in the application.

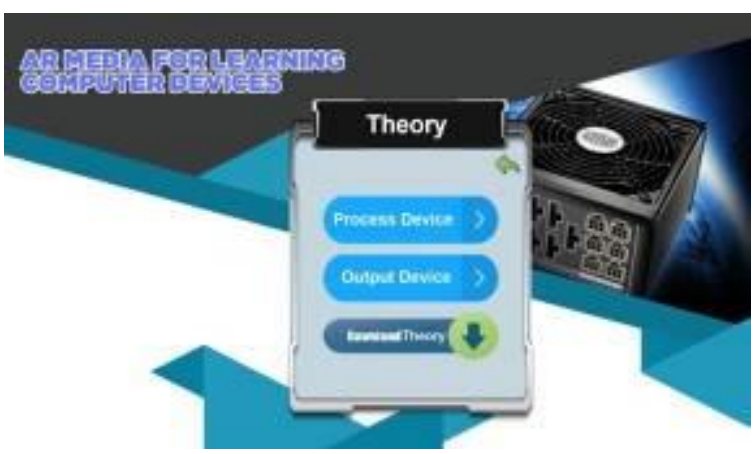

Figure 15. Material Menu Display

Discussion material displayed by the user will direct to the content page of the material concerned. The following is a display of the contents of the material in the form of a video.

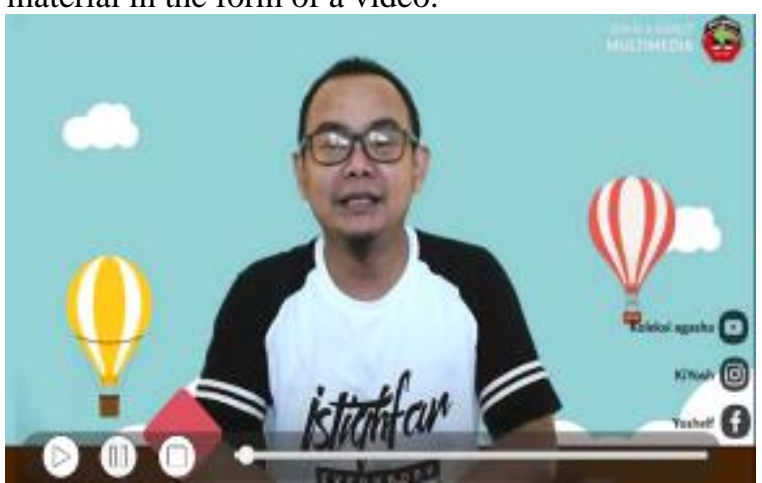

Figure 16. Content of the exercise display.

Before doing the exercise/quiz, the exercise menu display will display an information page first. 


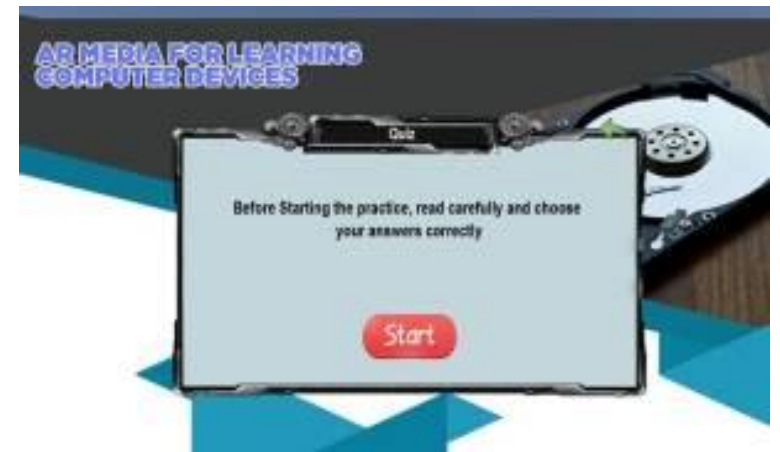

Figure 17. Display Before Doing Exercises

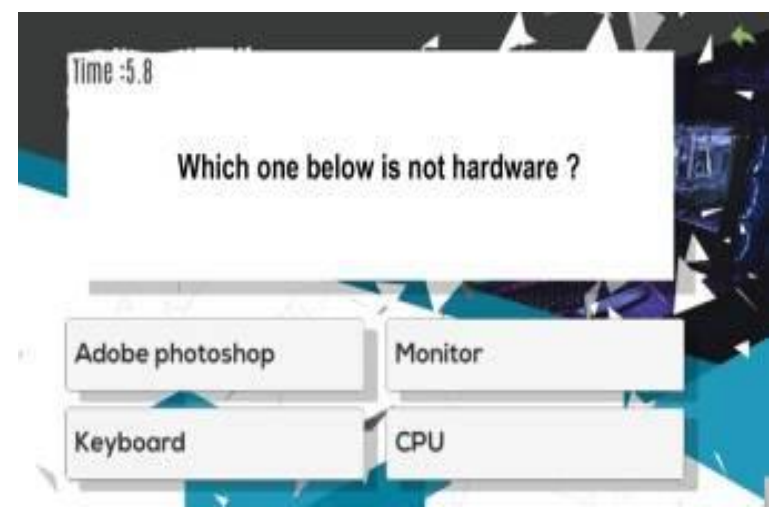

Figure 18. Display of Doing Exercises

\section{CONCLUSION}

Several conclusions can be made from designing augmented reality-based computer device recognition media on the android platform. The results show; (1) with this application it can help the learning process to be more effective than the previous one; (2) with the use of Augmented Reality-based media, Teachers will have it more comfortable to explain about computer hardware easily; and (3) this application is an offline application; no internet connection required.

\section{ACKNOWLEDGMENT}

Thankful to the Informatics Engineering Education Study Program of Padang State University for the opportunity to do research.

\section{REFERENCES}

[1] A. Huda, Asrul, and D. Kurniadi, "AndroidBased Ganto.or.id News Portal Mobile Application," J. Vocational Tek. Electron. Inform., vol. 3, no. 1, pp. 1-10, 2015.

[2] D. Hidayat and D. Irfan, "Designing of a Padang State University Campus Plan Application Using Augmented Reality Based on Android," J.
Vocational Tek. Electron. and Inform., vol. 6, no. 2, pp. 75-84, 2018.

[3] M. Permai, "Application of technology," Pros. SNATIF 1, pp. 267-274, 2014.

[4] F. Muhammad, A. Hadi, and D. Irfan, "Development of Android-Based Information System for Natural Disaster Mitigation Guidelines for West Sumatra Province," $J$. Teknol. Inf. and Educators., vol. 11, no. 1, pp. 27-42, 2018, DOI: 10.24036 / tip.v11i1.93.

[5] I. Bhouri, "On the projections of generalized upper Lq-spectrum," Chaos, Solitons and Fractals, vol. 42, no. 3, pp. 1451-1462, 2009, DOI: 10.1016 / j.chaos.2009.03.056.

[6] Novaliendry, D., Darmi, R., Hendriyani, Y., Nor, M., \& Azman, A. (2020). Smart Learning Media Based on Android Technology. International Journal of Innovation, Creativity and Change., 12(11), 715-735.

[7] Yang, C., Novaliendry, D., Chen, J., Wattimena, F. Y., Renyaan, A. S., Lizar, Y., ... Nasution, T. (2020). Prediction of Mortalityinthe Hemodialysis Patient with Diabetes using Support Vector Machine. Revista Argentina de Clínica Psicológica, XXIX, 219-232. https://doi.org/10.24205/03276716.2020.823

[8] Hendriyani, Y., Effendi, H., Novaliendry, D., \& Effendi, H. (2019). Augmented Reality Sebagai Media Pembelajaran Inovatif Di Era Revolusi Industri 4.0. Jurnal Teknologi Informasi Dan Pendidikan, 12(2), 62-67. https://doi.org/10.24036/tip.v12i2.244

[9] D. Novaliendry, Y.Hendriyani, C-H.Yang, \& H. Hamimi, 2015, The Optimized K-Means Clustering Algorithms to Analyezed the Budget Revenue Expenditure in Padang. Proceeding of International Conference on Electrical Engineering, Computer Science and Informatics, 61-64.

[10] Cowling, M., \& Birt, J. (2015). Teaching complex theoretical multi-step problems in ICT networking through 3D printing and augmented reality. In T. Reiners, B.R. von Konsky, D. Gibson, V. Chang, L. Irving \& K. Clarke (Eds.), Globally connected, digitally enabled. Proceedings ascilite 2015 in Perth (pp. CP:62CP:66).

[11] Cowling, M.; Tanenbaum, J.; Birt, J.; Tanenbaum, K. Augmenting reality for 
augmented reality. Interactions 2016, 24, 42-45. [CrossRef]

[12] Moro, C.; Štromberga, Z.; Stirling, A. Virtualisation devices for student learning: Comparison between desktop-based (Oculus Rift) and mobile-based (Gear VR) virtual reality in medical and health science education. Australas. J. Educ. Technol. 2017, 33, 1-10. [CrossRef]

[13] Birt, J.; Moore, E.; Cowling, M. Improving paramedic distance education through mobile mixed reality simulation. Australas. J. Educ. Technol. 2017, 33, 69-83. [CrossRef]

[14] Moro, C.; Štromberga, Z.; Raikos, A.; Stirling, A. The effectiveness of virtual and augmented reality in health sciences and medical anatomy. Anat. Sci. Educ. 2017, 10, 549-559. [CrossRef] [PubMed]

[15] Novaliendry, D., \& Andriani, S. English Edugame Application for Childhood base on Android. Jurnal RESTI (Rekayasa Sistem Dan Teknologi Informasi), 4(1), 187-192, 2020. 